Ann. Biol. anim. Bioch. Biophys., 1978, 18 (2 B), 555-563.

\title{
Action of hormones on Sertoli cells during maturation
}

\author{
by I. B. FRITZ, B. G. LOUIS, P. S. TUNG, Jennifer DORRINGTON \\ Banting and Best Department of Medical Research \\ University of Toronto, Ontario, Canada.
}

\begin{abstract}
Summary. The hypothesis is presented that testicular somatic cells, appropriately stimulated by hormones, produce a micro environment within the seminiferous tubule required for germinal cell development, but that germinal cells do not respond directly to androgens or gonadotropins. Emphasis is directed towards an analysis of the properties of cultured Sertoli cells, prepared from testes of rats of varying ages. Studies on the stimulation by FSH of CAMP production, $17 \beta$-estradiol synthesis and DNA synthesis by Sertoli cells during maturation have revealed greatest responsiveness in cells from immature rats. In Sertoli cells prepared from festes of rats 30 days-old or older, these responses are diminished or become non-detectable. The formation of androgen binding protein by cultured Sertoli cells prepared from 5-day old rats is not initially stimulated by FSH or androgens, but during the third to seventh days of culture, both hormones increase the production of this protein. Other changes occurring during maturation of Sertoli cells, either in vivo or in vitro, are shown to include characteristic structural modifications, and the appearance of a unique antigenic determinant on the plasma membrane of Sertoli cells at a time corresponding approximately to the time of formation of the blood-testis barrier. This surface component, which may serve as a maturation marker for Sertoli cells, is being explored as a possible candidate for modulating interactions with germ cells.
\end{abstract}

\section{I. - Introduction.}

For the past several years, our laboratory has investigated the properties of Sertoli cells in culture. We chose to investigate the biochemical responses of Sertoli cells to hormones because it appears likely that normal Sertoli cell function is required to permit spermatogenesis to proceed. In this communication, we shall briefly review the basis for this hypothesis, followed by a presentation of some of our recent findings on the properties of Sertoli cells during different stages of maturation.

\section{II. - Likely cellular targets in the testis for hormones.}

It is generally accepted that luteinizing hormone (LH) acts on the Leydig cell, which is the only testicular cell which has been shown to bind labeled LH specifically (for review, see Catt and Dufau, 1976). LH elicits a rapid increase in cAMP formation in Leydig cells, leading to a rise in the synthesis of testosterone (Catt and Dufau, 1976 ; Moyle and Ramachandran, 1973). LH does not increase CAMP formation in Sertoli 
cells (Cooke et al., 1972 ; Dorrington and Fritz, 1974a and b). The other major gonadotropin which affects testicular function is follicle stimulating hormone (FSH), which binds specifically to Sertoli cells but not to Leydig cells (Means and Vaitukaitis, 1972 ; Means and Huckins 1974 ; Steinberger ef al., 1974). FSH increases cAMP production in Sertoli cells, but not in Leydig cell preparations (Dorrington and Fritz, 1974a and $b$; Dorrington et al., 1975). Greatest effects are obtained in cells from testes of immature animals, or from regressed testes of hypophysectomized adult rats (Dorrington and Fritz, 1974a and b). Neither LH nor FSH has thus far been reported to act directly on germinal cells or on peritubular myoid cells. The influences of prolactin on Leydig cell functions have been recently reviewed (Bartke, 1976), and will not be considered here.

Testosterone action requires a specific cytoplasmic receptor which eventually is transported to the cell nucleus of responsive cells. In ffm mutants, this androgen receptor is non-functional, and such animals fail to respond to androgens (Ohno, 1971 ; Bardin et al., 1973). The tfm locus, carried on the $X$ chromosome, is normally inactivated during the early prophase of meiosis (Monesi, 1974), suggesting that primary spermatocytes and more developed germinal cells do not have the capacity to synthesize or regulate this androgen receptor. Further genetic evidence has been provided by Lyon ef al. (1975), who succeeded in producing allophenic mice having a mosaic of $X$ tfm $Y$ and $X+Y$ cells. Testes from two of these animals generated spermatozoa bearing the tfm mutation. The production of these sperm has been interpreted to signify that germinal cells can develop normally in the absence of a direct androgen response, provided normal somatic cells surround the germinal cells in the seminiferous tubule (Lyon ef al., 1975). This conclusion is based on the assumption that all androgen responses are dependent on the presence of a functional specific androgen receptor. Sertoli cells (Mulder et al., 1976) and peritubular myoid cells (Sar ef al., 1975) are known to contain androgen receptors. These and related data, which have been more extensively reviewed elsewhere (Fritz, 1977), permif the conclusion that somatic cells are probably the exclusive targets in the testis for androgens.

The role of the myoid cells in spermatogenesis is obscure, and relatively little is known concerning the nature of their response to testosterone. In contrast, extensive information on the biology, biochemistry, and hormone responsiveness of Sertoli cells is becoming available from various laboratories (for review, see Fritz, 1977). Possible means by which Sertoli cells could influence germinal cell development are actively being explored. We feel that available data can most readily be interpreted by assuming that LH acts exclusively on Leydig cells, FSH acts exclusively on Sertoli cells, and testosterone acts directly on the somatic cells of the festis but not on the germinal cells. Our work is currently based on the hypothesis that somatic cells, properly stimulated, produce a micro environment required for germinal cell development, and germinal cells do not respond directly to androgens or gonadotropins.

\section{III. - Actions of FSH on Sertoli cells at different stages of development.}

FSH greatly increases several processes in cultures of Sertoli cells prepared from testes of immature rats ranging in age from 5 to 30 days old. Thus, cAMP production is enhanced (Dorrington et al., 1974 ; Dorrington and Fritz, 1974a ; Steinb erger and 
Steinberger, 1976 ; Means ef al., 1976), and there are increased rates of synthesis of androgen binding protein (ABP) (Fritz et al., 1974, 1975, 1976a, b), estradiol from testosterone (Dorrington and Armstrong, 1975 ; Armstrong ef al., 1975), and DNA from labeled thymidine (Griswold ef al., 1976, 1977). The addition of (bu) $)_{2}$ cAMP or other CAMP derivatives duplicates all of the late responses in Sertoli cells elicited by FSH, and choleratoxin elicits similar effects (Fritz ef al., 1975, 1976a). These findings are consonant with the possibility that FSH actions on Sertoli cells are mediated by cAMP.

FSH influences on Sertoli cells are greatest in preparations from immature animals. For example, in the presence of phosphodiesterase inhibitors, FSH increases CAMP production by Sertoli cells from 20 day old rats by over 10 -fold (Dorrington ef al., 1975). However, the effect diminishes during maturation, so that the increase is reduced to 6 -fold in tubules prepared from 26 day old rats, 3-fold in preparations from 34 day-old rats, and only 2-fold in tubules from 75 day-old animals (Dorrington and Fritz, 1974b). Qualitatively similar findings have been reported by others (Steinberger and Steinberger, 1976). The diminution during development cannot be attributed to an increased phosphodiesterase activity because the phenomenon is evident when the phosphodiesterase inhibitor theophylline is present (Dorrington and Fritz, 1974b).

FSH or (bu) $)_{2}$ CAMP increases DNA synthesis by Sertoli cells prepared from testes of rats up to $\mathbf{4 0}$ days old. Largest relative effects are obtained in preparations from 20-day old rats, and no increase is seen in preparations from rats older than 40 days of age (Griswold et al., 1977). This diminution of responsiveness to FSH during maturation is not simply a consequence of a decreased capacity to elevate cAMP levels, but also reflects a decreased response by Sertoli cells to CAMP derivatives. These findings could reflect the presence of sub-populations of Sertoli cells which mature at different rates.

FSH or (bu) $)_{2}$ CAMP also increases the formation of $17 \beta$-estradiol from testosterone by Sertoli cells prepared from testes of immature rats (Dorrington and Armstrong, 1975 ; Armstrong ef al., 1975 ; Dorrington et al., 1976a). The magnitude of the effect is greater than 50 -fold in preparations from 5 -day old rats. However, it is reduced to about 10-fold in Sertoli cells from 20-day old rats. Further, in the presence or absence of MIX, FSH no longer enhances estradiol synthesis by cells prepared from rats 30 days of age or older (Dorrington ef al., 1976b). Interestingly, the same diminution in responsiveness is observed when (bu) $)_{2}$ CAMP is added to Sertoli cells prepared from testes of rats of increasing age (Dorrington et al., 1976b). From these results, it appears that during Sertoli cell maturation, complex and coordinate events are occurring which reduce the capacity of the cell to increase cAMP production in response to $\mathrm{FSH}$, and which abolish at least two "late responses 》 (increased DNA synthesis and stimulation of the aromatase pathway) to added (bu) ${ }_{2}$ cAMP or FSH.

Not all responses elicited by FSH are greatest in Sertoli cells from very young rats. For example, the production of $A B P$ by cells prepared from testes of 5-day old animals is not increased by the addition of FSH or testosterone during the first three days of culture. During subsequent periods of culture (from the third to the seventh day), FSH elicits a two-fold increase (fig. 1). Testosterone also increases ABP produc- 
tion in these preparations (fig. 1), just as it does in cells prepared from 20-day old rats (Louis and Fritz, 1977).

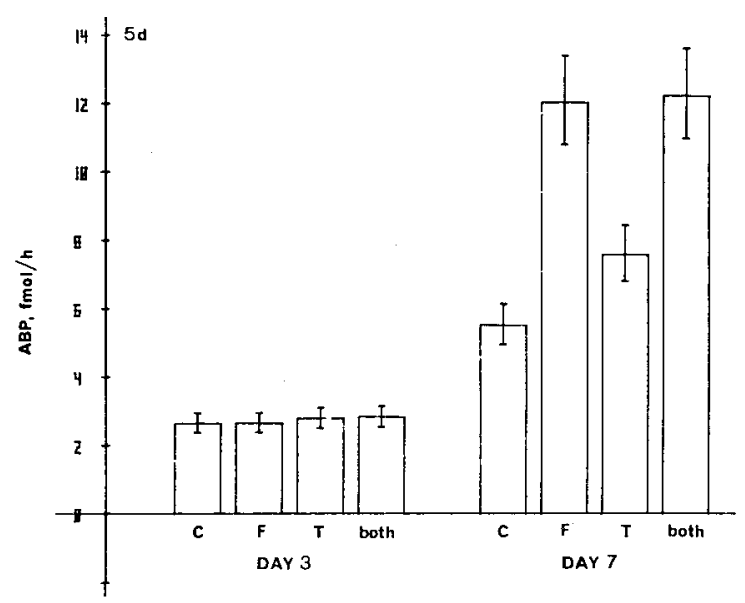

FIG. 1. - ABP production by Sertoli cells prepared from testes of 5 day-old rats, and cultured in a chemically defined medium (Louis and Fritz, 1977). ABP secreted into the medium was determined as previously described. When present, the concentrations of FSH (NIH-S-12) (F) and testosterone (T) employed were $1 \mu \mathrm{g} / \mathrm{ml}$ and $5 \times 10^{-7} \mathrm{M}$, respectively. Hormones indicated were added at the time of plating and during each change of medium thereafter. Data are shown as mean $\pm 95 \mathrm{p}$. 100 confidence limits

During the early periods of post-natal development, remarkable structural changes are taking place in the Sertoli cell (Flickinger, 1967 ; Gilula ef al., 1976). Changes in ultrastructure similar to those occurring in vivo have recently been observed in Sertoli cells prepared from testes of 10-day old rats and cultured for varying periods of time up to 2 weeks (Solari and Fritz, 1977). This includes the formation of a large nucleolus within an irregularly shaped nucleus; the formation of an extensive smooth-endoplasmic reticulum; and the formation of specialized tight junctions between cells (Solari and Fritz, 1977). Freeze-fracture electron microscopic examination reveals the presence of extensive junctional complexes in the cultured Sertoli cells (fig. 2). These maturation-like ultrastructural changes are most readily evident in Sertoli cells cultured in the presence of FSH or (bu) $)_{2}$ cAMP, perhaps reflecting the altered biochemical responses during maturation reported above. The relatively rapid changes in shape and structure of Sertoli cells after FSH addition have been previously described (Tung ef al., 1975 ; Tung and Fritz, 1975). From these observations, it could be anticipated from examination of the altered volumes and surface areas of the developing cells that the plasma membranes are also likely to be affected during matura-

FIG. 2. - Freeze-fracture electron micrograph of Sertoli cells prepared from testes of 20 day-old rats and cultured for 7 days in MEM containing $0.1 \mathrm{mM}$ dibutyryl cyclic AMP. Gap-junctional complexes (arrows) and extensive tight junctional complexes (arrowheads) are evident in numerous locations within the plasma membrane. Note that gap junctions are often in close proximity to the tight junctions ( $\times$ 47,900) (Lea, Burdzy and Fritz : in preparation.) 


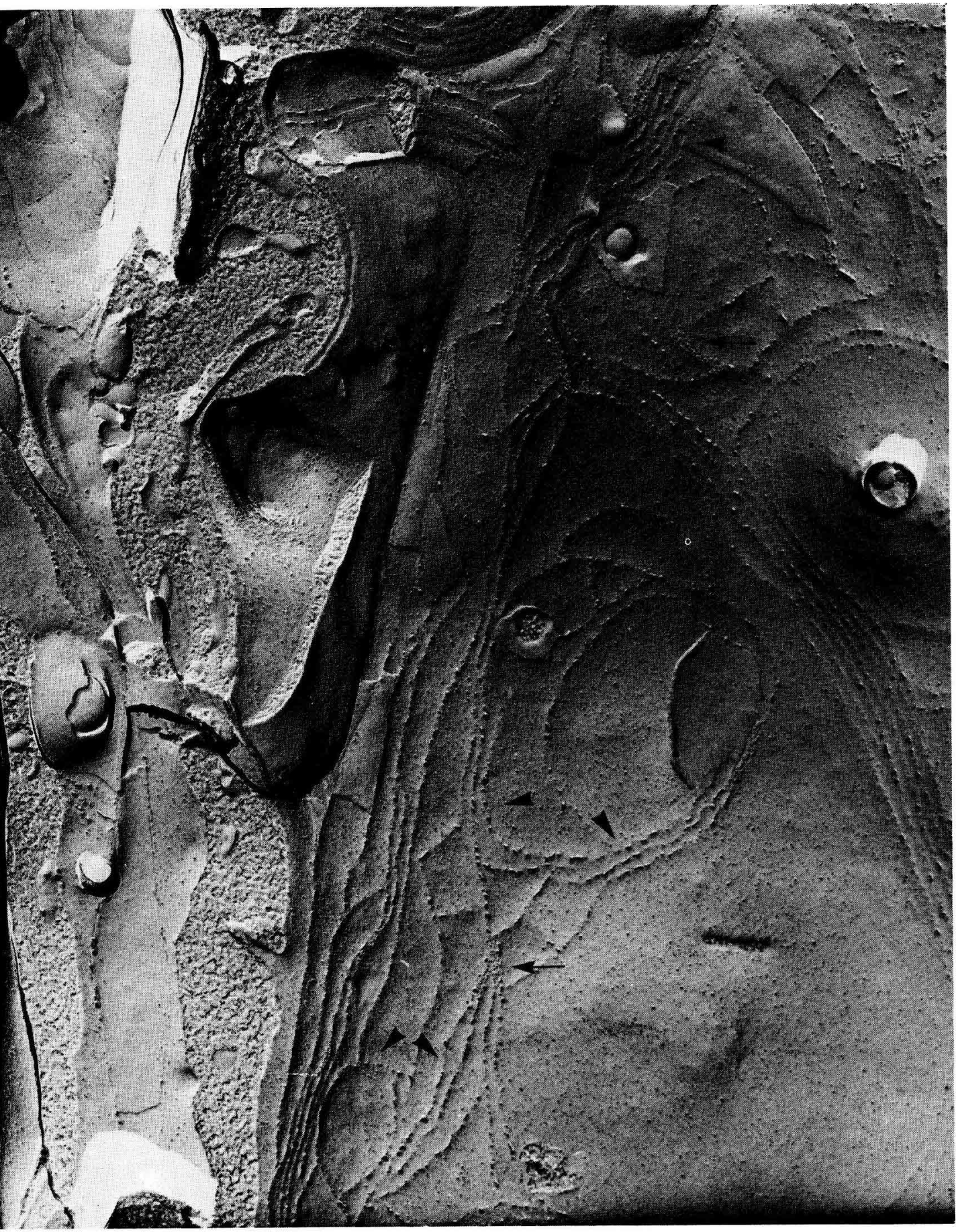


tion. Evidence indicating that a qualitative alteration in plasma membranes does indeed occur during development has been obtained in investigations of the antigenic surface components of maturing Sertoli cells. Male inbred Lewis-Wistar rats were challenged with cultured Sertoli cells prepared from 36-38-day old rats of the same inbred strain. Serological assays employed included FITC indirect immunofluorescent fests, horseradish peroxidase-labeled IgG for ultrastructural localization, and specific binding assays using 125 labeled antibody.

The unabsorbed antisera raised in inbred rats appeared to be organ-specific but not cell-specific. $\left.\right|^{\mathbf{1 2 5}}$ labeled $\mathrm{IgG}$ prepared from unabsorbed antisera bound to all cell types identified in the seminiferous epithelium, including peritubular myoid cells, but it did not bind to red blood cells or to cells isolated from rat brain, liver, kidney, spleen, thymus, and skeletal muscle. Antiserum absorbed by particulate fractions of testes from 12-day old rats, and by germ cells isolated from mature rat testes and epididymides, still retained binding activity to cultured Sertoli cells from maturing (38-day old) and mature (60-day old) rats (table 1). Peritubular myoid cells and interstitial cells in culture were not reactive to the absorbed antibody. In contrast, when the antiserum was absorbed by particulate fractions of whole testes from adult rats, or by cultured Sertoli cells prepared from 36 to 38-day old rats, the reactivity of the remaining moiety against Sertoli cells was non-detectable.

TABLE 1

Binding of ${ }^{125} \mathrm{l}-\mathrm{lg} \mathrm{g}$ to rat cells

\begin{tabular}{|c|c|}
\hline 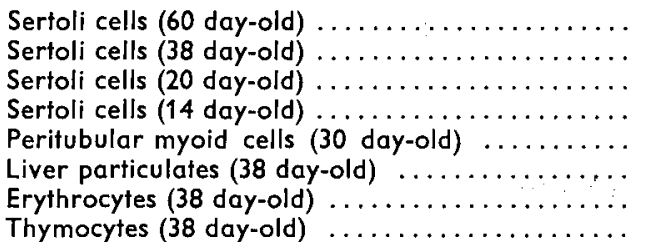 & $\begin{array}{r}68,900 * \\
52,500 \\
10,610 \\
1,240 \\
1,970 \\
860 \\
430 \\
620\end{array}$ \\
\hline
\end{tabular}

* IgG, prepared from serum of Lewis/Wistar rats immunized against Sertoli cells from 38 day-old-rats of the same strain, was absorbed against particulates of testis prepared from 12 day-old rats, and then iodinated with ${ }^{125}$ by the lactoperoxidase procedure. ${ }^{125}|-| g G$, having a specific activity of $1.6 \times 10^{6} \mathrm{CPM} / \mathrm{mg}$ protein, was incubated with cells indicated for $30 \mathrm{~min}$ at room temperature under saturating conditions. The cells were then washed in buffer, and $\mathbf{1 2 5}$ adsorbed was counted. Non-specific adsorption was determined by incubating cells with ${ }^{125} /$-lg $G$ prepared from nonimmunized rats. These blank values were subtracted to obtain values shown in the table, which are the mean of two separate determinations.

With antisera raised in inbred rats and partially purified by selective absorption, the initial appearance of the specific Sertoli cell antigen could be detected in extremely low quantity, randomly distributed on the plasma membranes of Sertoli cell 
colonies prepared from rats 18-20 days of age. The quantity of the reactive Sertoli cell specific antigen became progressively greater in Sertoli cells prepared from older animals. Immature Sertoli cells prepared from testes of 10-day old rats, and subsequently culfured in MEM supplemented with 10 p. 100 calf serum, progressively acquired increasing specific reactivity with the absorbed antibody, as determined by indirect immunofluorescent microscopy and specific binding assays.

These observations prompt us to suggest that an antigen arises in the plasma membrane of maturing Sertoli cells at about the time of formation of the blood-testis barrier. This antigen is probably unique to maturing or mature Sertoli cells, and is absent from other testicular cells. Hence, it seems appropriate to consider this antigen a maturation marker of the Sertoli cell. Our findings support the concept that specific intracellular differentiation of the plasma membrane is involved during Sertoli cell maturation. The role of $\mathrm{FSH}$ and androgens in these processes remains to be determined. We are currently investigating the appearance of this antigenic marker on the surfaces of cultured Sertoli cells prepared from 10-day old rats, and maintained in a chemically defined medium in the presence of various hormones. Experiments are in progress to determine if components appearing on the plasma membranes of Sertoli cells during maturation play any role in the interactions of Sertoli cells with germinal cells. The chemical nature of the antigenic determinant, and factors controlling its production, are being explored.

27 e Congrès infernational des Sciences physiologiques,

Symposium « Germ and somatic cell interaction 》

Paris, 21-23 juillet 1977.

Acknowledgments. - Work reviewed in this manuscript was supported by grants from the Canadian MRC and the Banting Foundation.

Résumé. Les cellules somatiques du testicule, convenablement stimulées par les hormones, produiraient à l'intérieur du tube séminifère un micro-environnement nécessaire au développement des cellules germinales, qui ne répondraient pas directement aux androgènes et aux gonadotropines. L'accent a été mis sur l'analyse des propriétés des cellules de Sertoli préparées à partir de testicules de différents âges et cultivées.

L'étude de la stimulation par FSH de l'AMPc, du $17 \beta$-estradiol ef de I'ADN des cellules de Sertoli tout au long de la maturation, montre une plus grande aptitude à répondre des cellules provenant de rats immatures. La réponse des cellules de Sertoli provenant de testicules de rats de 30 jours ou plus est diminuée ou devient indéłectable.

La formation, pendant la culture, de l'« androgen binding protein » par les cellules de Sertoli de rats de 5 jours n'est pas stimulée au début par FSH ou les androgènes, mais du $3^{\mathrm{e}}$ au $7^{\mathrm{e}}$ jour de culture, ces hormones augmentent la synthèse de cette protéine.

Les autres changements se produisant pendant la mafuration des cellules de Sertoli, soit in vivo, soit in vitro, concernent des modifications structurales caractéristiques et l'apparition d'un antigène membranaire approximativement au moment où se forme la barrière sang/tube séminifère. On recherche actuellement ce composant de surface qui peut servir d'indicateur de la maturation des cellules de Sertoli et constituer un modulateur dans les interactions avec les cellules germinales. 


\section{References}

ARMSTRONG D. T., MOON Y. S., FRITZ I. B., DORRINGTON J. H., 1975. Synthesis of estradiol-17 $\beta$ by Sertoli cells in culture : stimulation by FSH and dibutyryl cyclic AMP, 85-96. In FRENCH F. S., HANSSON V., RITZÉN E. M., NAYFEH S. N., Hormunal regulation of spermatogenesis, Curr. Top. Mol. Endocrinol., Vol. 2, Plenum Press, New York.

BARDIN C., BULLOCK L. P., SHERINS R. J., MOWSZOWICZ I., BLACKBURN W. R., 1973. Androgen metabolism and mechanism of action in male pseudohermaphroditism : a study of testicular feminization. Rec. Prog. Hormone Res., 29, 65-105.

BARTKE A., 1976. Role of prolactin in the regulation of testicular function, 136-152. In HUBINONT P. P., L'HERMITE M., SCHWERS J., Sperm action, Prog. Reprod. Biol., Vol. 1, Karger, Basel.

CATT K. J., DUFAU M. L., 1976. Basic concepts of the mechanism of action of peptide hormones. Biol. Reprod., 14, 1-15.

COOKE B. A., VAN BEURDEN W. M. O., ROMMERTS F. F. G., VAN DER MOLEN H. J., 1972 . Effect of trophic hormones on $3^{\prime}, 5^{\prime}$-cyclic AMP levels in rat testis interstitial tissue and seminiferous tubules. FEBS Letters, 25, 83-86.

DORRINGTON J. H., ARMSTRONG D. T., 1975. Follicle-stimulating hormone stimulates estradiol-17ß synthesis in cultured Sertoli cells. Proc. nat. Acad. Sci. (USA), 72, 2677-2681.

DORRINGTON J. H., FRITZ I. B., 1974a. Effects of gonadotrophins on cyclic AMP production by isolated seminiferous tubules and interstitial cell preparations. Endocrinology, 94, 395-403.

DORRINGTON J. H., FRITZ I. B., 1974b. Cell types influenced by FSH in the rat testis, 500-511. In MOUDGAL N. R., Gonadotropins gonadal function, Acad. Press, New York.

DORRINGTON J. H., FRITZ I. B., ARMSTRONG D. T., 1976a. Site at which FSH regulates estradiol$17 \beta$ biosynthesis in Sertoli cell preparations in culture. Molec. cell. Endocrinol., 6, 117-122.

DORRINGTON J. H., FRITZ I. B., ARMSTRONG D. T., 1976b. Control of estrogen synthesis by cultured Sertoli cells. Progr. Vth int. Congr. Endocrinol., Abstr. 768, 316.

DORRINGTON J. H., ROLLER N. F., FRITZ I. B., 1974. The effects of FSH on cell preparations from the rat testis, 237-241. In DUFAU M., MEANS A. R., Hormone binding and target cell activation in the testis, Plenum Press, New York.

DORRINGTON J. H., ROLLER N. F., FRITZ I. B., 1975. Effects of follicle siimulating hormone on culfures of Sertoli cell preparations. Molec. cell. Endocrinol., 3, 57-70.

FLICKINGER C. J., 1967. The postnatal development of the Sertoli cell of the mouse. Z. Zellforsch. Mikroskop. Anat., 78, 92-113.

FRITZ I. B., 1977. Sites of action of androgens and FSH on cells of the seminiferous tubule. In LITWACK G., Biochemicol actions of hormones, Vol. 5 (in press).

FRITZ I. B., GRISWOLD M. D., LOU!S B. G., DORRINGTON J. H. 1976a. Similarity of responses of cultured Sertoli cells to cholera toxin and FSH. Molec. cell. Endocrinol., 5, 289-294.

FRITZ I. B., KOPEC B., LAM K., VERNON R. G. 1974. Effects of FSH on levels of androgen binding and target cell activation in the testis, 311-327. In DUFAU M., MEANS A. R., Hormone binding and farget cell activation in the testis, Plenum Press, New York.

FRITZ I. B., LOUIS B. G., TUNG P. S., GRISWOLD M., ROMMERTS F. G., DORRINGTON J. H., 1975. Biochemical responses of cultured Sertoli cell-enriched preparations to follicle stimulating hormone and dibutyryl cyclic AMP, 367-382. In FP.ENCH F. S., HANSSON V., RITZÉN E. M., NAYFEH S. N., Hormonal regulation of spermatogenesis, Plenum Press, New York.

FRITZ I. B., ROMMERTS F. G., LOUIS B. G., DORRINGTON J. H., 1976b. Regulation by follicle stimulating hormone and dibutyryl cyclic AMP of androgen binding protein formation by Sertoli cell-enriched cultures. J. Reprod. Fertil., 46, 17-24.

GILULA N. B., FAWCETT D. W., AOKI A., 1976. Ultrastructural and experimental observations on the Sertoli cell junctions of the mammalian testis. Devel. Biol., 50, 142-168.

GRISWOLD M., MABLY E., FRITZ I. B., 1976. FSH stimulation of DNA synthesis in Sertoli cells in culture. Molec. cell. Endocrinal., 4, 139-149.

GRISWOLD M. D., SOLARI A., TUNG P. S., FRITZ I. B., 1977. Stimulation by FSH of DNA synthesis and of mitosis in cultured Sertoli cells prepared from testes of immature rats. Molec. cell. Endocrinol., 7, 151-165. 
LOUIS B. G., FRITZ I. B., 1977. Stimulation by androgens of the production of androgen binding protein by culfured Sertoli cells. Molec. cell. Endocrinol., 7, 9-16.

LYON M. F., GLENISTER P. H., LAMOREUX M. L., 1975. Normal spermatozoa from androgenresistant germ cells of chimaeric mice and the role of androgen in spermatogenesis. Nature, 258, 620-622.

MEANS A. R., FAKUNDING J. L., HUCKINS C., TINDALL D. J., VITALE R., 1976. Follicle stimulating hormone, the Sertoli cell and spermatogenesis. Rec. Prog. Hormone Res., 32, 477-527.

MEANS A. R., HUCKINS C., 1974. Coupled events in the early biochemical actions of FSH on the Sertoli cells of the testis, 145-165. In DUFAU M. L., MEANS A. R., Hormone binding and target cell activation in the testis, Plenum Press, New York.

MEANS A. R., VAITUKAITIS J., 1972. Peptide hormone receptors, Specific binding of $\left({ }^{3} \mathrm{H}\right)$-FSH to testis. Endocrinology, 90, 39-46.

MONESI V., 1974. Nucleoprotein synthesis in spermatogenesis, 59-87. In MANCINI R. E., MARTINI L., Male fertility and sterility, Acad. Press, New York.

MOYLE W. R., RAMACHANDRAN J., 1973. Effect of LH on steroidogenesis and cyclic AMP accumulation in rat Leydig cell preparations and mouse fumor Leydig cells. Endocrinology, 93, 127-134.

MULDER E., PETERS M. J., VAN BEURDEN W. M. O., GALDIERI M., ROMMERTS F. F. G., JANSZEN F. H. A., VAN DER MOLEN H. J., 1976. Androgen receptors in isolated cell preparations obtained from rat testis tissue. J. Endocrinol., 70, 331-332.

OHNO S., 1971. Simplicity of mammalian regulatory systems inferred by single gene determination of sex phenotypes. Nature, 234, 134-137.

SAR M., STUMPF W. F., MCLEAN W. S., SMITH A. A., HANSSON V., NAYFEH S. N., FRENCH F. S., 1975. Localization of androgen farget cells in the rat festis autoradiographic studies, 311 322. In FRENCH F. S., HANSSON V., RITZÉN E. M., NAYFEH S. N., Hormonal regulation of spermatogenesis, Plenum Press, New York.

SOLARI A., FRITZ I. B., 1977. The ultrastructure of immature Sertoli cells maturation-like changes during culture, and the maintenance of mitotic potentiality. Biol. Reprod. (submitted for publication).

STEINBERGER A., STEINBERGER E., 1976. Action of gonadotropins in testis organ and cell culture, 42-54. In HUBINONT P. P., L'HERMITE M. L., SCHWERS J., Sperm action, Prog. Reprod. Biol., Vol. 1, Karger, Basel.

STEINBERGER A., TANKI K. J., SIEGAL B., 1974. FSH binding in rat testes during maturation and following hypophysectomy, 177-191. In DUFAU M. L., MEANS A. R., Hormone binding and targef cell activation in the testis, Plenum Press, New York.

TUNG P. S., FRITZ I. B., 1975. FSH and dibutyryl cyclic AMP directed changes in ultrastructure and properties of cultured Sertoli cell-enriched cultures comparison with cultured testicular perifubular cells, 495-508. In FRENCH F. S., HANSSON V., RITZÉN E. M., NAYFEH S. N., Hormonal regulation of spermologenesis, Plenum Press, New York.

TUNG P. S., DORRINGTON J. H., FRITZ I. B., 1975. Structural changes induced by follicle stimulating hormone or dibutyryl cyclic AMP on presumptive Sertoli cells in culture. Proc. nat. Acad. Sci. (Wosh.), 72, 1838-1842. 